\title{
BSA Adsorption and Immobilization onto Charged Monodisperse Polymer Nanoparticles
}

\author{
Masahiro Yasuda ${ }^{1 *}$, Kentaro Ono ${ }^{1}$, Takashi Nomura1, Scott H Brewer ${ }^{2}$, Oyvind Halskau $\mathrm{Jr}^{3}$, Sondre Volden ${ }^{4}$ and Wilhelm R Glomm ${ }^{4}$ \\ ${ }^{1}$ Department of Chemical Engineering, Osaka Prefecture University, Naka-ku, Sakai, Osaka, Japan \\ ${ }^{2}$ Department of Chemistry, Franklin and Marshall College, Lancaster, USA \\ ${ }^{3}$ Department of Molecular Biology, University of Bergen, Biosense Laboratories AS Thormohlensg, Norway \\ ${ }^{4}$ Department of Chemical Engineering, Norwegian University of Science and Technology, Norway
}

\begin{abstract}
Controlling the behavior of adsorbed and immobilized proteins is essential for protein purification and a wide range of applications, including biosensors, biocatalysis and biomedical devices. In this study, monodisperse polymer particles were synthesized by soap free emulsion polymerization and the surface functional groups were directly introduced as a monomer or chemically modified with epoxy groups to enable protein immobilization through covalent bonding. Three kinds of surface charged particles having cationic, anionic, or both, groups were synthesized and characterized. Bovine serum albumin (BSA) was selected as a model protein to study the effect of $\mathrm{pH}$ of a buffer solution containing protein on the adsorption and immobilization amount. Protein adsorption was found to be strongly affected by $\mathrm{pH}$ and matching of the global protein and polymer particle charges, respectively. When $\mathrm{pH}$ was below the $\mathrm{pl}$ of either protein $(\mathrm{pH} 3.8)$, negatively charged polymer particles were found to adsorb a high amount of proteins. At maximum surface coverage of BSA on negatively charged polymer particles at $\mathrm{pH} 3.8$ and after subsequent rinsing of the BSA-polymer particle complex with phosphate buffer (pH 7), 50\% of BSA was desorbed. Therefore, $50 \%$ of BSA was adsorbed by ionic interaction and the remaining fraction was immobilized covalently at $\mathrm{pH}$ 3.8. The remaining immobilized fraction was sufficient to completely shield the anionic charge of the polymer particles. Fluorescence spectroscopy suggests that at maximum immobilized amounts, the conformation of immobilized BSA appears to be the same as in aqueous solution.
\end{abstract}

Keywords: Monodisperse polymer particles; Protein conformation; Molecular spectroscopy; Protein immobilization; Bovine serum albumin

\section{Introduction}

A conformation change of protein is one of the most important studies for biochemistry and biotechnology. Protein conformation regulates its functions, such as interaction with other molecules, catalytic activity, binding against various specific targets, the formation of three dimensional constitution, motility characteristic of muscle or flagellum, and so on $[1,2]$. To utilize proteins for use of medicine, catalyst, bioactive reagents, the relationship between their conformation and their functions is important. However, it is very difficult to clarify a mechanism and pathway of the conformational change of various proteins including their denaturation. This was because the majority of micro-domain conformational change was depended on the amino acid sequence of protein [3] and these processes was controlled by many factors, such as steric hindrance, interaction with other amino acids residue or other organic compounds, hydrogen bonding, covalent disulfide bonding, folding behavior of helix and sheet micro domain, and so on. Nowadays, from the protein refolding and the studies using $\mathrm{X}$-ray analysis, a collapse of regular and cyclic three dimensional conformations, such as $\alpha$ - helix and $\beta$ - sheet, have been well studied using BSA [4], RNAse [5], and lysozyme [6] as a model protein. For the refolding study, protein conformation has various substantial states and the existence of intermediate has been proved [7]. From the study of properties of the intermediate states formed at equilibrium folding and unfolding of globular proteins, the structural description of these intermediates was studied and the existence of thermodynamically stable intermediates between the native and fully unfolded states was proved. This class of intermediate states has been called the "molten globule" intermediate state [7]. Conformational change between native form and molten globule is very slow and reversible. When protein attains molten globule form, it lacks quickly three dimensional conformation and becomes random coil conformation [8].

Enzymes are usually not stable at a high temperature and in the presence of organic solvents. Therefore, while enzymatic reactions in organic solvents or aqueous solutions containing organic solvents have several advantages [9], enzymatic reactions were limited within their stable reaction conditions. To overcome this disadvantage, enzyme immobilization is effective and many researches to develop thermal stable, $\mathrm{pH}$ stable, and organic solvent tolerant enzymes [10] have been taking place. Enzyme immobilization is regarded as the effective method to keep protein conformation native [11]. However, there is few studies concerning conformational change on the support and the effect of immobilization on the conformational change is still unclear. Furthermore, nowadays some disease, such as Alzheimer's and Parkinson's, were caused by the conformation change and their critical step was the formation of toxic multimeric, soluble $\beta$-sheet aggregates and subsequent precipitation of amyloid fibrils is the time-dependent $\alpha$ -helix $\rightarrow \beta$-sheet assembly [12]. Some measurement systems for protein

*Corresponding author: Masahiro Yasuda, Department of Chemical Engineering Osaka Prefecture University,1-1 Gakuen-cho, Naka-ku, Sakai, Osaka, Japan, Tel: +81 72254 9299; E-mail: yasuda@chemeng.osakafu-u.ac.jp

Received September 14, 2015; Accepted October 07, 2015; Published October 17,2015

Citation: Yasuda M, Ono K, Nomura T, Brewer SH, Halskau Jr O,et al. (2015) BSA Adsorption and Immobilization onto Charged Monodisperse Polymer Nanoparticles. J Biosens Bioelectron 6: 183. doi:10.4172/2155-6210.1000183

Copyright: @ 2015 Yasuda M, et al. This is an open-access article distributed under the terms of the Creative Commons Attribution License, which permits unrestricted use, distribution, and reproduction in any medium, provided the original author and source are credited. 
conformation change on a support have been developed. However, these methods had some restrictions for colloidal stability, low amount of immobilized proteins, dispersity of aqueous solution, and overlap of spectra with protein. Therefore, there is a need for a new system which can measure at various $\mathrm{pH}$ values, in the presence of organic solvent, and can immobilize large amounts of protein on its surface.

The objective of this work is to develop a support of protein immobilization with free restriction and the evaluation of conformation change of immobilized proteins on the support. For this purpose, three kinds of monodisperse polymer particles having cation, anion, or both ions were synthesized by soap free emulsion polymerization and chemical modification of surface function group as a first stage. Then, BSA was adsorbed and immobilized at various $\mathrm{pH}$ and protein concentrations. Finally, the amount of immobilized protein, zeta potential of immobilized protein on polymer particle at various $\mathrm{pH}$, fluorescence spectra of immobilized protein were measured to analyze conformation change of immobilized protein.

\section{Materials and Methods}

2,2'-Azobis (amidino propane) dichloride salt was purchased from Wako Pure Chemical Co. (Osaka, Japan). Ammonia aqueous solution (25\%) and hydrochloric acid were purchased from VWR PROLABO International (Paris, France). Ammonium persulfate, bovine serum albumin (BSA), 1,4-butanediol diglycidyl ether, chloroform, coomassie brilliant blue G-250, disodium hydrogen phosphate, divinyl benzene ( $80 \%$ mixture of isomers), glycidyl methacrylate (GMA), sodium tetraborate decahydrate, and styrene monomer were purchased from Sigma-Aldrich Co. (ST. Louis, MO, USA). Orthophosphoric acid (85\%) and acetic acid were purchased from E. MERCK KG (Darmstadt, Germany). All of the reagents were used without purification.

\section{Polymer particle synthesis}

Polymer particles for protein adsorption support were synthesized by soap-free emulsion polymerization [13]. First, $1.8 \mathrm{~g}$ of GMA, 0.04 $\mathrm{g}$ of divinyl benzene, $1.2 \mathrm{~g}$ of styrene monomer and $95 \mathrm{ml}$ of water were added to a $300 \mathrm{ml}$ five-neck reaction flask. The reaction vessel was immersed in an oil bath at $70^{\circ} \mathrm{C}$, and the reaction mixture was stirred at $100 \mathrm{rpm}$ for $15 \mathrm{~min}$. When the temperature of the reaction mixture reached $70^{\circ} \mathrm{C}, 0.06 \mathrm{~g}$ of initiator was dissolved in $5 \mathrm{ml}$ of water and the resulting initiator aqueous solution was added to the reaction mixture. After 2 hours, $0.3 \mathrm{~g}$ of GMA was added to the reaction mixture. The reaction mixture was heated for 16 hours. Monomer conversion was measured by a gravimetric method, and the amount of epoxy groups on the polymer particles was measured by the hydrochloric aciddioxane method [14]. Following polymerization, the reaction mixture was centrifuged at 13,000 rpm for $10 \mathrm{~min}$, and the precipitated polymer particles were suspended in distilled water. Centrifugation, discarding the supernatant and suspending polymer particles with distilled water (hereafter referred to as particle wash) was repeated three times. In the case of synthesis of polymer particles having both anionic and cationic surface groups, $1 \mathrm{~g}$ of negatively charged polymer particles was dispersed in $3 \mathrm{M}$ of ammonia solution using ammonium persulfate as an initiator and incubated at $70^{\circ} \mathrm{C}$ for 24 hours. Produced polymer particles were washed and dispersed in $100 \mathrm{ml}$ of $100 \mathrm{mM}$ 1,4-butanediol diglycidyl ether aqueous solution. The particle suspension was incubated for 24 hours at $30^{\circ} \mathrm{C}$. After the reaction, the polymer particles were suspended in water and stocked with a refrigerator $\left(4^{\circ} \mathrm{C}\right)$. The synthesized particles are hereafter referred to as cationic polymer particles (cationic $\mathrm{PP}$ ), anionic polymer particles (anionic PP), and zwitterionic polymer particles (zwitterionic PP) depending on their surface charge.

\section{Protein adsorption and immobilization on polymer particles}

In this study, epoxy groups introduced on the polymer particle surface were reacted with amino groups on the protein [15], such as lysine, histidine and arginine residues, and protein was covalently adsorbed on the polymer particle. To investigate the effect of adsorption on the protein conformation, we chose BSA as a model protein. The $\mathrm{pH}$ of the protein solutions was regulated using either $10 \mathrm{mM}$ of sodium acetate ( $\mathrm{pH} 3.8)$, sodium phosphate $(\mathrm{pH} 7.0)$, or sodium borate $(\mathrm{pH}$ 9.0 ) as buffer solutions. In the adsorption step, $10 \mu \mathrm{M}$ of protein stock solution in water, polymer particle suspended in buffer solution, 100 $\mathrm{mM}$ buffer stock solution, and Milli-Q water until the final buffer concentration was $10 \mathrm{mM}$ were added to a $2 \mathrm{ml}$ poly(propylene) sample tube. The final mixture contained $1 \mu \mathrm{M}$ of BSA and $7.5 \mathrm{mg}$ of polymer particle, respectively. The total volume of the mixture was adjusted to $2 \mathrm{ml}$. The adsorbed amounts at $4^{\circ} \mathrm{C}$ were measured after of 24 hour incubation. The mixture of protein and polymer particle was incubated at $4^{\circ} \mathrm{C}$ for times ranging from $5 \mathrm{~min}$ to 24 hours. Following adsorption, the sample tube was centrifuged at $14,500 \mathrm{rpm}$ for $10 \mathrm{~min}$ and the remaining protein concentration in the supernatant was measured. Centrifuged polymer particles were washed and suspended in fresh buffer solution. The amount of adsorbed protein on the polymer particles was calculated by the difference between the initial protein concentration of a reference solution and the protein concentration remaining in the supernatant. Protein concentration was measured using the Bradford method [16].

\section{Polymer particle characterization and analysis of adsorbed and immobilized protein}

A 1000-fold diluted solution of the polymer particle stock solution (75 mg. $\mathrm{ml}^{-1}$ ) with Milli-Q water was loaded into a $1 \mathrm{~cm} \times 1 \mathrm{~cm}$ poly (styrene) cell, and polymer particle size and its distribution were measured using a Zetasizer 3000HSA (Malvern Instrument Ltd., Malvern, UK). The zeta potentials of the polymer particles, protein solution, and protein adsorbed on polymer particles were measured using a Zetasizer Nano ZS (Malvern). Here, $10 \mathrm{ml}$ of the sample solution was prepared and loaded into the $\mathrm{pH}$ titration unit (MPT-2, Malvern). $\mathrm{pH}$ of the sample solution was varied from 3 to 10 using $0.25 \mathrm{M}$ of sodium hydroxide or $0.25 \mathrm{M}$ of hydrochloric acid. The $\mathrm{pH}$ adjusted sample solution was circulated in the Zetasizer and zeta potentials at various $\mathrm{pH}$ were automatically measured. FE-SEM microphotographs were taken using a JSM-6700FW (JEOL, Tokyo, Japan). The particle pore size and its distribution were measured by $\mathrm{N}_{2}$ gas adsorption apparatus (Micromeritics, Norcross, GA, USA). Here, $0.5 \mathrm{~g}$ of sample was added to the glass sample tube and degaussed using a VacPrep 061 sample degaussing system. Particle pore size and its distribution were analyzed by BET isotherm theory [17], using the BJH method under the assumption of cylindrical pores [18]. Fluorescence emission spectra were measured using a Fluorolog-3 (Horiba Jobin Yvon, Paris, France). Protein solution or a mixture of protein and particle was added to the quartz cell and the detector was placed in the $90^{\circ}$ direction against an excitation beam. The excitation and emission slit widths were set at 5 $\mathrm{nm}$ and the integration time was $5 \mathrm{sec}$. For calibration, fluorescence emission spectra of the particle suspension in various buffer solutions were also measured. In the case of adsorbed and immobilized protein, fluorescence emission spectra included particle contribution for fluorescence emission spectra. To obtain fluorescence emission spectra of immobilized protein, measured fluorescence emission spectra were numerically divided from the fluorescence emission spectra of particles. 


\section{Results and Discussion}

\section{Synthesis and characterization of monodisperse polymer particles}

Three types of charged monodisperse polymer particles having epoxy groups were synthesized by soap free emulsion polymerization of glycidyl methacrylate, styrene and divinyl benzene, with divinyl benzene acting as a cross-linking agent. Figure 1 illustrates the synthesis procedures employed here. It should be noted that the anionic polymer particles can also be synthesized using ammonium persulfate as initiator, and the cationic polymer particles can also be synthesized using 2,2'-azobis (amidino propane) dihydrochloride salt. The epoxy groups on the anionic polymer particles were further decomposed using aqueous ammonia, and cationic amino groups were introduced. In order to introduce epoxy groups onto the particles, one side of the epoxy group of 1,4-butanediol diglycidyl ether was reacted with a particle surface amino groups.

The particle size distributions were measured by dynamic light scattering. Average particle sizes of anionic PP, cationic PP, and zwitterionic PP were about $200 \pm 20 \mathrm{~nm}$ with very narrow ( monodisperse) size distributions. The particle surface appeared smooth and no surface pores could be observed from the SEM microphotographs.

From zeta potential measurements in Milli-Q water, the average zeta potential of anionic PP, cationic PP, and zwitterionic PP were $-46,27$, and $10 \mathrm{mV}$, respectively. Table 1 shows mean zeta potentials of particles in $10 \mathrm{mM}$ of various buffer solutions. Although there are some buffer effects on the zeta potential of the polymer particles, zeta potential value of anionic $\mathrm{PP}$, cationic $\mathrm{PP}$, and zwitterionic $\mathrm{PP}$ show that the anionic PP remained negatively charged throughout the entire $\mathrm{pH}$ region studied here. The cationic $\mathrm{PP}$ remained positively charged in the $\mathrm{pH}$ range between $\mathrm{pH} 3.8$ and $\mathrm{pH}$ 8.0, with the value of the zeta potential decreasing with increasing $\mathrm{pH}$ values. When $\mathrm{pH}$ is 9.0, amidino group of cationic PP is neutralized by borate ions and its surface has a negative charge. For the zwitterionic PP, the cationic groups were dominant under acidic conditions, whereas the anionic surface groups dominated the charge behavior under basic $\mathrm{pH}$ conditions. The zwitterionic $\mathrm{PP}$ display an isoelectric point between $\mathrm{pH}$ 5.0 and $\mathrm{pH} 6.0$ Table 1. Thus, we can introduce the desired charge on the particle surface, with all of the surface charges being homogeneous except for the zwitterionic PP.

From the surface area distribution of anionic PP measured by BET $\mathrm{N}_{2}$ adsorption Table 2, there is some hint of mesopores between $8 \mathrm{~nm}$ and $48 \mathrm{~nm}$ in anionic PP. The total surface area of the pores ranging $2 \mathrm{~nm}$ to $43 \mathrm{~nm}$ was $15.7 \mathrm{~m}^{2}$ (g-particles) ${ }^{-1}$. The outer surface area of anionic PP was calculated to be $27.6 \mathrm{~m}^{2}$ (g-particles) ${ }^{-1}$ (one gram of particle was $2.17 \times 10^{14}$ particle calculated by its density $\left(1.1 \times 10^{3} \mathrm{~kg}\right.$ $\mathrm{m}^{-3}$ ) and the surface area per particle was calculated by multiplying this value with $\left(\pi \times\left(200 \mathrm{~nm} \times 10^{-9}\right)^{2}\right)$. Both results are roughly similar value to the calculated outer surface area.

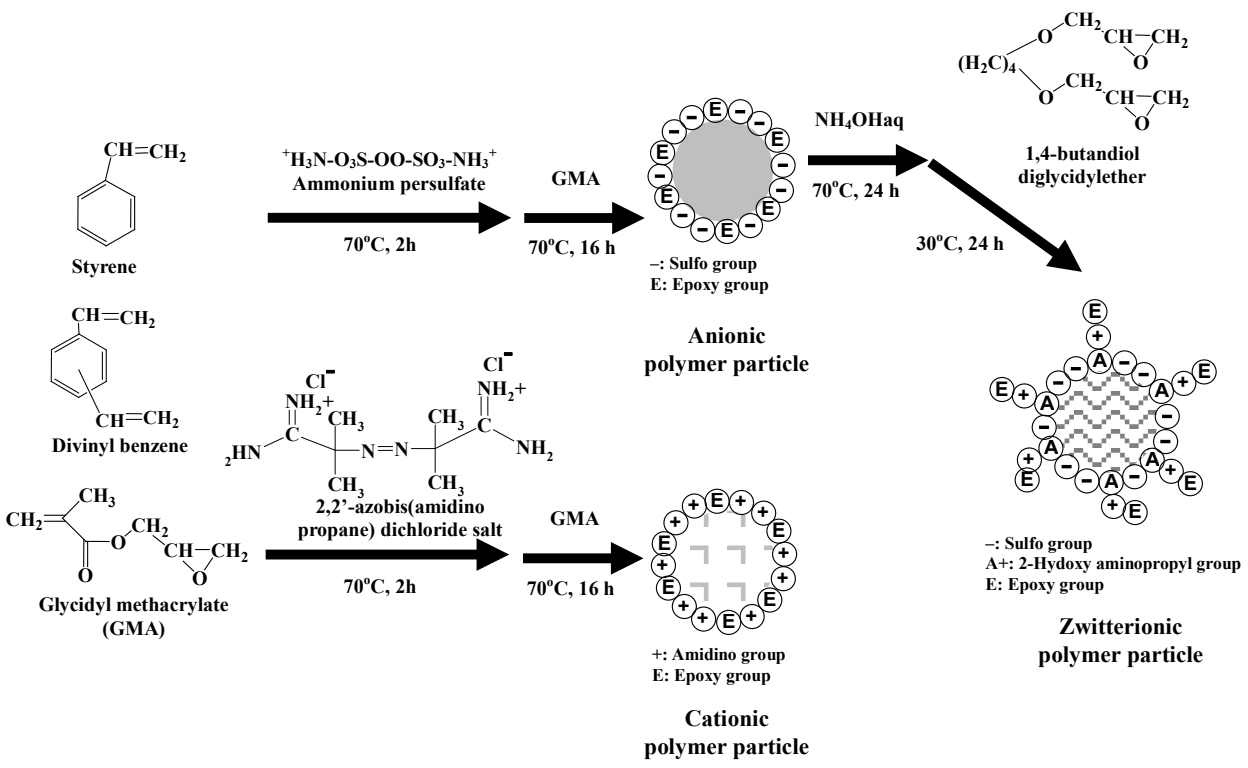

Figure 1: The synthesis procedures of polymer particle.

\begin{tabular}{|c|c|c|c|c|c|c|}
\hline \multirow{4}{*}{ Particle } & \multicolumn{6}{|c|}{ Zeta potential in $10 \mathrm{mM}$ of buffer solution $(\mathrm{mV})$} \\
\hline & Sodium acetate & Sodium phosphate & Sodium phosphate & Sodium phosphate & Sodium phosphate & Sodium borate \\
\hline & \multicolumn{6}{|c|}{ pH (-) } \\
\hline & 3.8 & 5 & 6 & 7 & 8 & 9 \\
\hline Anionic PP & -33.4 & -18.2 & -19.4 & -19.3 & -19.4 & -34.9 \\
\hline Cationic PP & 31.5 & 6.3 & 6.4 & 5.7 & 4 & -24.4 \\
\hline Zwitterionic PP & 47.5 & 5.5 & -2.7 & -11.6 & -24.8 & -37.7 \\
\hline
\end{tabular}

Table 1: Zeta Potential of polymer particles in various buffer solutions. 


\begin{tabular}{|c|c|c|}
\hline \multicolumn{3}{|c|}{ BET $\mathrm{N}_{2}$ absorption isotherm } \\
\hline Average pore size & Incremental pore area & Cumulative pore area \\
\hline$(\mathrm{nm})$ & (m²/g-particles) & (m²/g-particles) \\
\hline 42.7 & 3.28 & 15.7 \\
\hline 29 & 3.75 & 12.4 \\
\hline 20.6 & 2.58 & 8.63 \\
\hline 16.1 & 1.25 & 6.05 \\
\hline 13.3 & 0.828 & 4.8 \\
\hline 11.2 & 0.574 & 3.97 \\
\hline 9.6 & 0.443 & 3.4 \\
\hline 8.4 & 0.298 & 2.96 \\
\hline 7.5 & 0.242 & 2.66 \\
\hline 6.7 & 0.171 & 2.42 \\
\hline 6.1 & 0.136 & 2.25 \\
\hline 5.5 & 0.096 & 2.11 \\
\hline 5.1 & 0.085 & 2.01 \\
\hline 4.7 & 0.088 & 1.93 \\
\hline 4.3 & 0.089 & 1.84 \\
\hline 4 & 0.075 & 1.75 \\
\hline 3.7 & 0.069 & 1.68 \\
\hline 3.5 & 0.074 & 1.61 \\
\hline 3.2 & 0.084 & 1.53 \\
\hline 3 & 0.111 & 1.45 \\
\hline 2.8 & 0.105 & 1.34 \\
\hline 2.6 & 0.114 & 1.23 \\
\hline 2.5 & 0.14 & 1.12 \\
\hline 2.3 & 0.169 & 0.98 \\
\hline 2.25 & 0.054 & 0.811 \\
\hline 2.2 & 0.065 & 0.757 \\
\hline 2.15 & 0.059 & 0.692 \\
\hline 2.1 & 0.049 & 0.633 \\
\hline 2.05 & 0.064 & 0.584 \\
\hline 2 & 0.06 & 0.52 \\
\hline 1.96 & 0.054 & 0.46 \\
\hline 1.93 & 0.064 & 0.404 \\
\hline 1.9 & 0.071 & 0.34 \\
\hline 1.85 & 0.083 & 0.269 \\
\hline 1.8 & 0.085 & 0.186 \\
\hline 1.7 & 0.101 & 0.101 \\
\hline$>1.7$ & 0 & 0 \\
\hline
\end{tabular}

Table 2: Pore area distribution measured by Bet $\mathrm{N}_{2}$ adsorption.

\section{BSA adsorption and immobilization on monodisperse polymer particles}

In addition to charged groups, the monodisperse polymer particles synthesized here were also functioned with epoxy groups which can react with amino groups such as lysine on the protein surface (Figure 1). We expected that the surface charge density matching between protein and polymer strongly affects the reaction probability between epoxy groups on the particles and protein amino groups. BSA is one of the most well-characterized proteins with respect to both structure and properties, and is known to reversibly change its conformation with $\mathrm{pH}$ [4]. The $\mathrm{pH}$-dependent BSA conformations have been classified as native form (around $\mathrm{pH} 7$ ), fast migrating form produced abruptly ( $\mathrm{pH}$ 3.5 - 4.3), expanded form $(\mathrm{pH}<3.5)$, and basic form $(\mathrm{pH}>8)[4,19]$. Moreover, albumin is the most abundant plasma protein. Therefore, it was a convenient model for the fundamental studies of protein adsorption and conformational change on the polymer particles. For BSA, the number of acidic amino acid residues (asparagine and glutamine) was 99 and the number of basic amino acid residues (lysine and arginine) was 82 [20]. An abundance of acidic amino acid residues results in an acidic pI, whereas basic amino acid residues form covalent bonds with epoxy group on the polymer particle. pIs of BSA are 4.85.0. From global charge considerations, we expected anionic PP to be the most efficient below pI, while cationic PP is most efficient above pI, with zwitterionic PP being capable of adsorption throughout the entire $\mathrm{pH}$ range studied here. To prevent $\mathrm{pH}$ changes attributed to the counter ions of the ionic polymer particles, three kinds of buffer systems were adopted here; at $\mathrm{pH} 3.8$ (sodium acetate buffer), 7.0 (sodium phosphate buffer), and 9.0 (sodium borate buffer). The maximum adsorbed amounts of BSA on the three kinds of polymer particle and three $\mathrm{pH}$ conditions studied here are shown in Table 3. To rule out non-specific protein adsorption, the protein-polymer particle constructs were precipitated by centrifugation and resuspended in a 10 $\mathrm{mM}$ buffer solution. This particle wash procedure was repeated three times. From the protein amount of removed supernatant and dilution ratio calculated from the added amount of buffer solution, the amount of liberated protein was negligible.

The amount of adsorbed protein is controlled by surface charge density matching between protein and polymer particles. When BSA was adsorbed on the anionic PP in acetate buffer ( $\mathrm{pH} 3.8$ ), the polymer particles precipitated slowly and reversibly in the course of 5 minutes. This indicates that the protein-particle constructs formed by the anionic PP softly aggregated, with the positive charge of adsorbed BSA acting as a binder between negatively charged particles.

In the case of cationic PP, amino groups derived from initiator fragments can react with epoxy groups on the polymer particle surface, lowering the number of surface epoxy groups [21]. The total epoxy amount of cationic PP was found to be $95 \%$ of that of anionic $\mathrm{PP}$. The decomposition of epoxy groups around the surface slightly contributed to the lower adsorbed amount of BSA. The adsorption mixture of cationic PP and BSA in $10 \mathrm{mM}$ phosphate buffer ( $\mathrm{pH} 7.0)$ also precipitated, whereas at $\mathrm{pH} 9$, only slight precipitation could be observed. However, at $\mathrm{pH} 9$, the adsorbed amount was small compared to that at $\mathrm{pH} 7$ (Table 3), resulting in a low protein-induced precipitation rate. This can be ascribed to negatively charged BSA adsorbed on the surface of cationic PP acting as a binder between cationic PP.

In the case of zwitterionic PP, epoxy groups of anionic PP were first reacted with ammonia, and the introduced 2-hydroxy amino group was further reacted with one end group of 1,4-butanediol diglycidyl ether Figure 1. Therefore, unreacted epoxy groups from 1,4-butanediol diglycidyl ether remained on the particle. Due to significant steric hindrance in the polymer network, the reaction between amino-

\begin{tabular}{|l|c|c|c|}
\hline \multirow{2}{*}{ Particle } & \multicolumn{3}{|c|}{ Maximum adsorbed amount } \\
\cline { 2 - 4 } & \multicolumn{3}{|c|}{ ( $\mathrm{kg}$-protein/mg-particle) } \\
\cline { 2 - 4 } & 3.8 & 7 & 9 \\
\hline Anionic PP & $28.86^{\mathrm{A}}$ & $0.79^{\mathrm{R}}$ & $0.33^{\mathrm{R}}$ \\
\hline Cationic PP & $1.00^{\mathrm{R}}$ & $2.02^{\mathrm{A}}$ & $0.96^{\mathrm{R}}$ \\
\hline Zwitterionic PP & $2.27^{\mathrm{R}}$ & $1.26^{\mathrm{R}}$ & $2.92^{\mathrm{R}}$ \\
\hline
\end{tabular}

A: attractive forces act between polymer particle and protein

$R$ : repulsive forces act between polymer particle and protein

A or $\mathrm{R}$ is judged by the $\mathrm{pl}$ of protein and Zeta potential of polymer particles in various buffer solution as shown in Table 1.

Table 3: Maximum adsorbed amount of BSA on polymer particles at various $\mathrm{pH}$. 
and epoxy groups was restricted to the particle surface [13]. The amount of epoxy groups $\left.(0.4 \mathrm{mmol} \text { (g-particle) })^{-1}\right)$ introduced to the particles as described here was severely limited by comparison with the introduction as a monomer $\left(4 \mathrm{mmol}(\mathrm{g} \text {-particle })^{-1}\right)$. However, the resulting adsorbed amount of BSA was high considering that the total epoxy amount of zwitterionic PP was about $10 \%$ of that of anionic PP (Table 3). Moreover, $\mathrm{pH}$ did not affect the amount of protein adsorbed on the zwitterionic PP due to the presence of both amino groups and sulfo groups. As shown in Table 3, protein adsorption is strongly dependent on the relationship between the surface charge of the polymer particle (A or R) and the global protein charge. Here, protein can access oppositely charged polymer particles, allowing amino groups on the protein to react with epoxy groups on the polymer particle surface. In other words, the reaction between epoxy groups on the polymer particles and amino groups on the protein is inhibited by the same charged ion barrier.

The adsorbed amount of BSA of anionic PP at pH 3.8 was the highest in all tested in this study and 10-20 times higher than finding at other conditions. This can be attributed to a severe increase of protein hydrophobicity close to the pI (BSA; 4.8-5.0), with concomitant formation of dimers or multiple protein aggregates [22]. BSA adsorption can be well explained by global charge density matching and their multimer formation. This can be explained either by multilayer formation of BSA on anionic PP, or by optimized packing of the protein layer under these conditions. Since a small portion of liberated protein could be detected from the precipitated and washed anionic PP in the presence of high concentration of salt and the majority of adsorbed protein was remaining on anionic $\mathrm{PP}$, we conclude that within the $\sim 1 \%$ detection sensitivity of this method, all of the remaining protein was covalently bound to the polymer particles. Fluorescence results, described below, are also consistent with this interpretation. As anionic $\mathrm{PP}$ at $\mathrm{pH} 3.8$ was found to result in maximum protein adsorption, these conditions were adopted for the remainder of this study.

\section{Protein adsorption kinetics}

When $7.5 \mathrm{mg}$ of polymer particles was added to $2 \mathrm{ml}$ of $1 \mu \mathrm{M}$ of BSA in $10 \mathrm{mM}$ of buffer solution and equilibrated for $24 \mathrm{~h}$ at $4^{\circ} \mathrm{C}$, free protein was detected in the supernatant after centrifugation (14500 $\mathrm{rpm}, 5 \mathrm{~min}$ ). This was because all of the available epoxy groups on the surface were occupied by the adsorbed protein, blocking additional free protein from further access to epoxy groups by centrifugation. Since BSA has 82 of lysine and arginin residues, respectively, multipoint covalent bonding could be formed at low fractional surface coverage, likely resulting in conformational changes in the adsorbed protein. Typically, the rate of conformational change after adsorption and aggregates formation of adsorbed protein (on a particle or between particles) are relatively slow compared to the reaction between protein amino groups and epoxy groups on the polymer particle. Therefore, a change in long term period was measured.

When the incubation time of polymer particles with protein solution was shortened to 3 hours, the adsorbed amounts were almost the same values as shown in Table 3. This indicates that the reaction between epoxy groups on the polymer particle and protein amino groups was complete after 3 hours. To further investigate the kinetics of protein adsorption, we measured time-dependent adsorption of $\mathrm{BSA}$ at the conditions of maximum protein adsorption (anionic PP at $\mathrm{pH} \mathrm{3.8)} \mathrm{from} 5 \mathrm{~min}$ to $60 \mathrm{~min}$. Since it took $5 \mathrm{~min}$ to precipitate polymer particles using centrifugation, we could not take obtain data points at shorter times than $5 \mathrm{~min}$. The adsorbed amounts of BSA from $5 \mathrm{~min}$ to $60 \mathrm{~min}$ were almost the same within the experimental error, indicating that the adsorption was completed within $5 \mathrm{~min}$ and the effect of conformational change in adsorption amount was negligible. Using unsteady state diffusion theory [23], we can estimate that the adsorption was finished within 0.35 - 3.49 seconds (it depended on the absorption amount of BSA on the particle). These results support that adsorption occurs almost instantly and maximum adsorption amount was attained within 5 minutes in our experimental condition in which excess amount of protein exists in the supernatant.

\section{Protein desorption from polymer particles}

BSA was adsorbed on three kinds of polymer particles, with the adsorbed amount being affected by $\mathrm{pH}$ as shown in Table 3 . To clarify whether the proteins were immobilized or adsorbed, i.e.; covalently or electrostatically attached, polymer particle-protein constructs were rinsed with $1 \mathrm{M}$ of $\mathrm{NaCl}$ aqueous solution after protein adsorption. When protein is adsorbed on ion-exchange resins, desorption is accomplished using aqueous solutions containing high concentration of salt [24]. Therefore, desorption of protein reveals whether ion interaction or epoxy group-amino group conjugation is predominant for protein adsorption on the polymer particles used here. Prior to the desorption experiment, protein desorption via use of centrifugation and buffer change was investigated, with neither process yielding any measurable desorption.

Under the conditions used in this study, the detection limit for the Bradford method was found to be a difference of $2 \mu \mathrm{g}(\mathrm{ml})^{-1}$. For a system consisting of $7.5 \mathrm{mg}$ polymer particles with an adsorbed amount of $28.86 \mu \mathrm{g}$ (mg-particle) $)^{-1}$, rinsing with $100 \mu \mathrm{l}$ of salt containing buffer resulted in $0.46 \%$ desorption of the adsorbed BSA. However, for systems with low immobilization amounts, such as $0.33 \mu \mathrm{g}$ (mg-

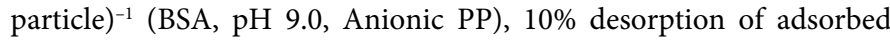
protein could be detected. Under conditions of maximum adsorbed amounts of BSA onto anionic PP (at pH 3.8; $28.86 \mu$ g (mg-particle) $)^{-1}$ ), addition of $1 \mathrm{M} \mathrm{NaCl}$ to the aqueous buffer resulted in $\sim 15 \%$ desorption of BSA. Interestingly, no desorption of BSA (except at $\mathrm{pH}$ 3.8) from polymer particle could be detected upon addition of $1 \mathrm{M} \mathrm{NaCl}$ to the buffer solutions, indicating that with the exception of BSA adsorbed onto anionic PP at $\mathrm{pH} 3.8$, BSA was covalently immobilized on the polymer particles.

Since BSA desorption was detected for BSA adsorption onto anionic $\mathrm{PP}$ at $\mathrm{pH} 3.8$, the effect of $\mathrm{pH}$ on the BSA desorption was further studied. After preparation of BSA adsorbed on anionic PP (28.86 $\left.\mu \mathrm{g}(\mathrm{mg} \text {-particle })^{-1}\right)$, BSA-polymer particle constructs were rinsed with $10 \mathrm{mM}$ of acetate buffer, precipitated by centrifuge and

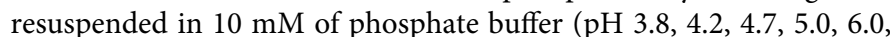
$7.0,8.0$, or 9.0 ) or $10 \mathrm{mM}$ of borate buffer ( $\mathrm{pH} 9.0$ ). In the region $\mathrm{pH}$ $6-10, \sim 50 \%$ desorption of BSA was measured, whereas at lower $\mathrm{pH}$ values, the percentage of desorbed BSA was measured to be $0,0,22.4$, and $43.6 \%$ at $\mathrm{pH} 3.8,4.2,4.7$, and 5.0, respectively. This result indicates that the reversibility of BSA adsorption, i.e.; desorption is strongly linked to the solution $\mathrm{pH}$ relative to the $\mathrm{pI}$ of BSA (4.8), and that $\sim 50 \%$ of BSA adsorbed onto anionic PP at pH 3.8 was desorbed by inversion of surface charge. This result also indicates that at $\mathrm{pH} 3.8, \sim 50 \%$ of BSA adsorbed onto anionic PP was adsorbed by ionic interaction and the remaining fraction was immobilized covalently. The desorption percentage resulting from addition of $1 \mathrm{M} \mathrm{NaCl}$ was significantly lower that resulting from a pH change in a $10 \mathrm{mM}$ buffer. When $10 \mathrm{mM}$ of $\mathrm{NaCl}$ was added to the suspension of anionic $\mathrm{PP}$ at $\mathrm{pH} 3.8$ on which $28.86 \mu \mathrm{g}(\mathrm{mg} \text {-particle })^{-1}$ of BSA was adsorbed, the desorbed amount is $50 \%$ of the adsorbed amount. Therefore, the high concentration of salt affects the inhibition of BSA desorption, and hydrophobic interactions 
attributed to salting out may be enhanced by the addition of salt.

Next, the effect of BSA surface concentration on desorption was

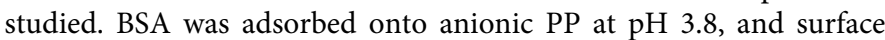
concentrations were varied from $1.88 \mu \mathrm{g}(\mathrm{mg} \text {-particle })^{-1}$ to $28.86 \mu \mathrm{g}(\mathrm{mg}$ particle $)^{-1}$. After the rinsing and centrifugation steps, BSA-PP constructs were resuspended in a $10 \mathrm{mM}$ phosphate buffer ( $\mathrm{pH}$ 7.0). Percentages of desorption for surface-bound BSA at surface concentrations of $28.86,19.48,10.75,5.05$, and $1.88 \mu \mathrm{g} \cdot(\mathrm{mg} \text {-particle })^{-1}$ were $50,23.7,0$, 0 , and $0 \%$, respectively. As expected, desorption is strongly dependent on the surface concentration, and the remaining amount of BSA was calculated to be 14-15 $\mu$ g (mg-particle $)^{-1}$. Since the excess adsorbed BSA on anionic PP at $\mathrm{pH} 3.8$ reached the same molar amount with that of immobilized BSA, we make the assumption that BSA forms dimers at $\mathrm{pH}$ 3.8. Rezwan et al. studied BSA adsorption on colloidal $\mathrm{Al}_{2} \mathrm{O}_{3}$ particles, and an adsorption model of BSA in which BSA forms dimers around $\mathrm{pH} 5.0$ (near pI of BSA) was presented [25]. The driving force of BSA dimer formation is hydrophobic interactions between the hydrophobic domain III of BSA molecules, which are enhanced close to the pI. At pH 3.8, the strongly positive charged domains I and II, where many of the $\varepsilon$-amino group of Lys are localized, approach the surface of the polymer particle by charge-charge interaction with sulfo groups on the anionic PP, placing the hydrophobic domain III in a reverse position against the particle surface in a side-on monolayer [25]. In turn, the exposed hydrophobic domain III of adsorbed BSA molecules is favorably positioned for interaction with hydrophobic domain III of free BSA, leading to surface-induced dimer formation. In our case, masking of surface charges attributed to sulfo groups on anionic PP by side-on monolayers was not complete, and $15 \%$ of adsorbed BSA residing as surface-bound dimers from charge-charge interaction with sulfo groups was desorbed by the addition of salt. As shown in Figure 2 , the difference between free BSA and adsorbed and immobilized BSA in $\mathrm{pH}$-zeta potential profile existed. Since $1 \mathrm{M}$ of $\mathrm{NaCl}$ addition to buffer solution enhanced hydrophobic interaction, the remaining $35 \%$

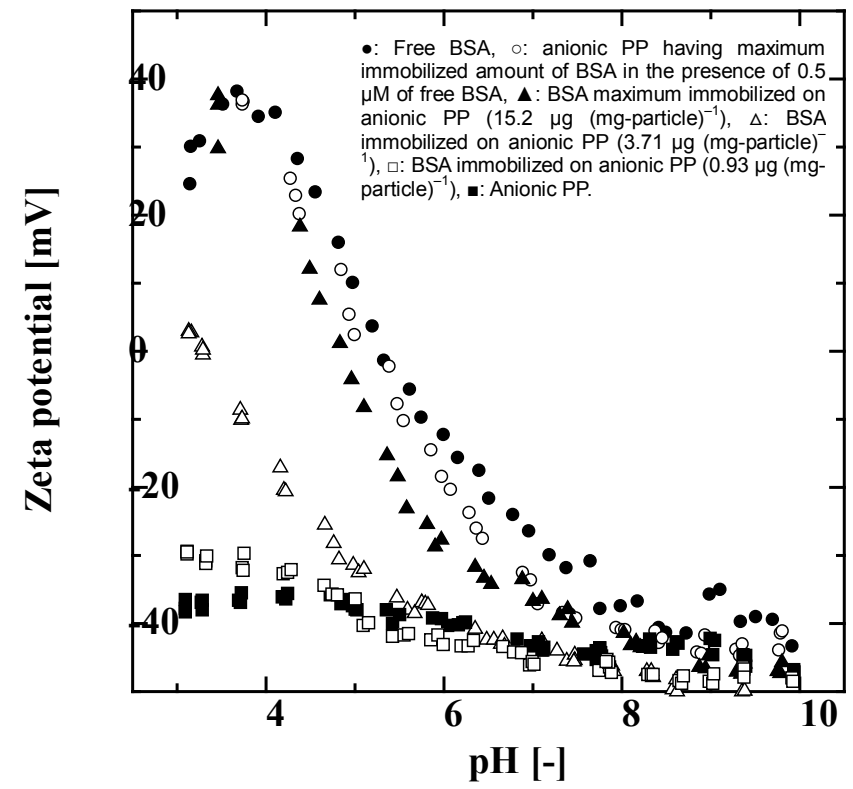

Figure 2: The effect of $\mathrm{pH}$ on the zeta potential of BSA immobilized anionic PP BSA was immobilized with $37.5 \mathrm{mg}$ of by anionic $\mathrm{PP}$ at $\mathrm{pH} 3.8$ under various BSA concentrations. Anionic PP was washed with Mili-Q water the centrifuge. Wash was repeated 3 times and the anionic PP was suspended in $10 \mathrm{ml}$ of Mili-Q water. $\mathrm{pH}$ was adjusted at 3.0 using $0.1 \mathrm{M}$ of $\mathrm{HCl}$ aqueous solution. of adsorbed BSA remained as a dimer layer. Upon increasing the $\mathrm{pH}$ above the $\mathrm{pI}$ of BSA, the global BSA charge changes from positive to negative, resulting in complete desorption of the outer, weakly bound layer of the BSA dimers.

\section{Effect of surface protein coverage on zeta potential of anionic PP}

To study whether the polymer particle surfaces were completely covered with protein and whether conformational changes occurred in the adsorbed protein, zeta potentials of anionic PP-protein constructs were measured in the $\mathrm{pH}$ interval between 3.0 and 10.0. The amount of adsorbed protein was varied from $5-100 \%$ of maximum surface coverage as described above and adsorbed protein was immobilized to anionic PP at these immobilization amounts. After adsorption, the anionic PP - protein constructs were washed with Milli - Q water to remove excess (free) protein and suspended in Milli - Q water. After adjusting $\mathrm{pH}$ to 3.0 with aliquots of $0.1 \mathrm{M} \mathrm{HCl}$, the zeta potentials of free protein, anionic PP, and anionic PP-protein constructs were measured as a function of $\mathrm{pH}$. Figure 2 shows the zeta potential titration curves of free and immobilized BSA. The zeta potential of anionic PP was strongly negative, ranging from - 48 to - $35 \mathrm{mV}$ in this $\mathrm{pH}$ region. For BSA only, the zeta potential is strongly positive at low $\mathrm{pH}(\mathrm{pH} 3-4)$, with the absolute value decreasing with increasing $\mathrm{pH}$. At $\mathrm{pH}$ 5.6, the zeta potential of BSA reaches zero, while at higher $\mathrm{pH}$ the protein shows a negative charge. The difference between $\mathrm{pI}$ reported by previous works [26] and that determined in this study may be attributed to the ionic strength of water, which is known to affect the pI of proteins [27]. When anionic PP - BSA constructs with maximum surface coverage were dispersed in the presence of $0.5 \mu \mathrm{M}$ free BSA, the resulting $\mathrm{pH}$ - zeta potential profile is very similar to that of anionic PP - BSA constructs at maximum surface coverage without any excess $\mathrm{BSA}$, with a pI residing between anionic PP - BSA at maximum surface coverage and that of free BSA. For this sample, the measured signal is the sum of contributions from free and immobilized BSA, yielding an intermediate $\mathrm{pH}$ - titration profile. At low $\mathrm{pH}$ values, the zeta potential of anionic PP - BSA constructs is shifted from positive to negative values with decreasing immobilization amounts, indicating that BSA completely blocks the anion charge of the polymer particle at maximum immobilization amount in this study as described in protein desorption from polymer particles.

From the surface area of anionic PP $\left(1.27 \times 10^{-2} \mathrm{~m}^{2} \text { (mg-particles) }\right)^{-1}$ (pore diameter is between $8.4 \mathrm{~nm}$ and $42.7 \mathrm{~nm}$ in Table 2) as calculated from the BET adsorption isotherm and the molecules number of 15.2 $\mu \mathrm{g}$ of BSA (composed of $1.35 \times 10^{14}$ molecules), we calculated the area occupied by one adsorbed BSA molecule to be $9.41 \times 10^{-17} \mathrm{~m}^{2}$ (BSA molecule $)^{-1}$. Here, we assume that BSA has an approximate spherical shape in aqueous solution. The hydrodynamic diameters of BSA at $\mathrm{pH}$ 3.8 were $7.9 \pm 0.9 \mathrm{~nm}$ measured by Zetasizer. We estimated the mean molecular projection area of one BSA molecule to be $4.90 \times 10^{-17} \mathrm{~m}^{2}$

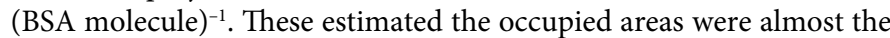
same level as that of occupied area, indicating that BSA completely covered the surface of anionic PP at $15.2 \mu \mathrm{g}$ (mg-particles) ${ }^{-1}$ of BSA immobilization amount.

\section{Steady-state fluorescence spectra of protein immobilized on anionic PP}

Fluorescence spectroscopy is regarded as a good technique with which to evaluate BSA conformational change. BSA has two tryptophan (Trp) residues, one of which resides close to the surface and one which is buried in the hydrophobic interior. Changes in the 
microenvironment surrounding the Trp residues of BSA result in a shift in the fluorescence emission as the residues become solvated. Figure 3 shows fluorescence emission spectra of immobilized BSA on anionic $\mathrm{PP}$ in $10 \mathrm{mM}$ acetate buffer at $\mathrm{pH}$ 3.8. BSA concentrations were varied from $0.4 \mu \mathrm{M}$ to $1.0 \mu \mathrm{M}$. Anionic PP-BSA constructs were washed and suspended in a $10 \mathrm{mM}$ acetate buffer at $\mathrm{pH} 3.8$ after immobilization. The fluorescence intensities were directly correlated to BSA concentration at all $\mathrm{pH}$ (data not shown) and the fluorescence intensities of adsorbed BSA were proportional to adsorbed amounts. However, at high adsorbed amounts, the correlation between BSA adsorption amount and emission intensity was lost. We attribute this to static quenching from the anionic PP [28] The maximum emission peak positions of the maximum immobilized BSA on anionic PP, (a) - (d), and free BSA at pH 3.8 were $358,355,354,353$, and 353 $\mathrm{nm}$, respectively. The maximum emission peak was increased with decreasing the immobilization amount. Red shift of maximum emission peak was attributed to the strong conjugation with anionic PP at a low immobilization amount. When BSA is present in excess relative to the amount required for complete surface coverage on the particles, the rate of BSA deposition was quite high as estimated in the section on protein immobilization kinetics, resulting in immobilization of BSA without conformational changes. However, at low fractional surface coverage, free epoxy groups remain after immobilization of BSA, which may result in conformational changes of the immobilized protein due to several covalent attachment points. Multipoint conjugation between epoxy groups on the surface and protein amino groups resulted in strong conjugation between BSA and the particle. The larger changes observed for lower fractional surface coverages are in agreement with the zeta potential titration curve trends observed for both proteins, as discussed above. This is also in agreement with general theory for adsorption of macromolecules. Briefly, each protein molecule must go through the following steps during immobilization: (1) transport towards the surface, (2) attachment, and (3) reorientation/spreading,

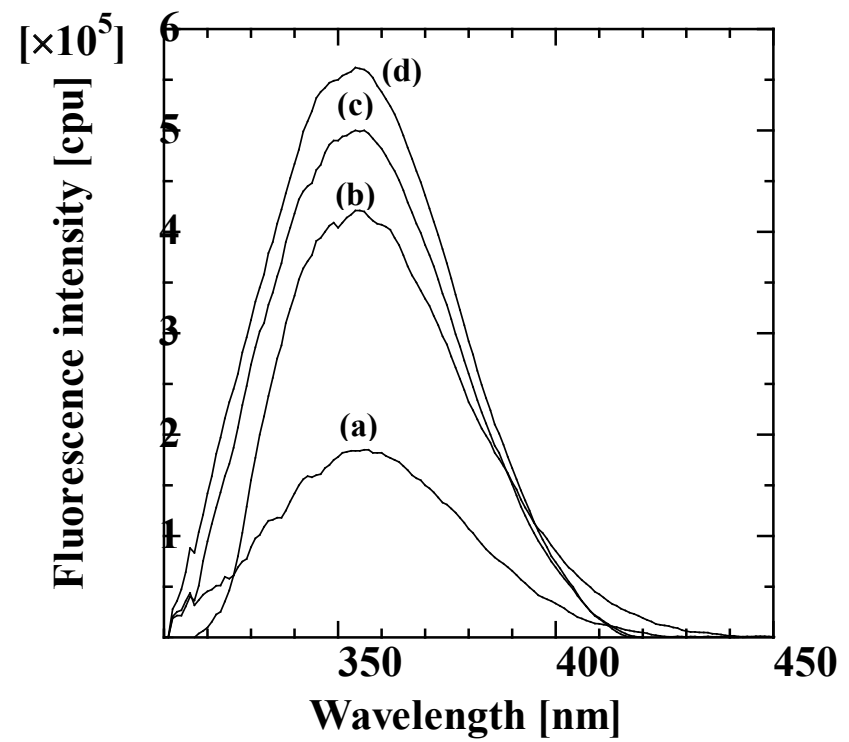

Figure 3: Fluorescence emission spectra of immobilized BSA in acetate buffer (pH 3.8). $3.75 \mathrm{mg}$ of Anionic PP and BSA were added to acetate buffer solution $(\mathrm{pH} 3.8)$ and incubated for $24 \mathrm{~h}$ at $40 \mathrm{C}$. BSA concentrations were $0.4,0.6$, 0.8 , and $1.0 \mu \mathrm{M}$, respectively. Immobilized BSA was washed and suspended with acetate buffer. The adsorption and immobilization amounts of BSA against anionic PP were (a) 4.73, (b) 8.96, (c) 13.8 and (d) $18.2 \mu \mathrm{g}$ (mg-particle)-1. Fluorescence excitation was took place at $295 \mathrm{~nm}$. with the latter step being responsible for conformational changes in the protein. Let $\tau_{i}$ be the time required to transport and immobilize proteins on the particle surface, and let $\tau_{\mathrm{s}}$ be the time required for the protein to reorient or spread following initial attachment. If $\tau_{i}>\tau_{s}$, each protein molecule can reorient and/or spread before it is surrounded by other molecules. Conversely, if $\tau_{\mathrm{s}}>\tau_{\mathrm{i}}$, each protein molecule will be enclosed by neighbors before it has time to reorient or spread. For a specific protein-surface interaction, $\tau_{\mathrm{s}}$ will likely be constant. However, as shown by Glomm et al. [26], $\tau_{\mathrm{i}}$ is tunable via bulk protein concentration and resulting fractional surface coverage. At or close to complete surface coverage, the protein is tightly packed and more likely to retain its native structure, whereas low fractional surface coverage in this case enables multipoint conjugation with available epoxy groups. In turn, this increases the degree of conformational changes, as indicated by the relationship between fractional surface coverage, zeta potential profiles and tryptophan emission spectra.

\section{Conclusion}

We have studied the synthesis and characterization of monodisperse charged nanosized polymer particles and concomitant protein immobilization on anionic, cationic and zwitterionic polymer particles, respectively. The synthesized polymer particles were not porous and their surface charge was controlled via the synthetic method. When the sign of the particle surface charge was the same as the global protein charge, the maximum adsorption amount was low while the maximum adsorption amount was high in the case of oppositely charged particles and protein. Protein adsorption was found to be complete within $5 \mathrm{~min}$ and all of the feed protein was adsorbed until maximum adsorption amount. When BSA was adsorbed onto anionic $\mathrm{PP}$ at $\mathrm{pH} 3.8$ and surface concentrations were varied from 1.88 $\mu \mathrm{g}$ (mg-particle) $)^{-1}$ to $28.86 \mu \mathrm{g}$ (mg-particle $)^{-1}$, BSA was immobilized on the polymer particle surface until about $15 \mu \mathrm{g}$ (mg-particle $)^{-1}$, after which an excess of BSA forms dimers on immobilized proteins. When excess BSA was adsorbed on polymer particle and protein-polymer particle complex was dipped in buffer solution in which global protein charge was reversed, protein desorption occurred.

From estimation of immobilized amount of protein and zeta potential measurements, the surface of the anionic PP were completely covered with BSA at the maximum immobilized amount in $10 \mathrm{mM}$ of acetate buffer at $\mathrm{pH} 3.8$, with BSA completely shielding the negative charge of the anionic PP. Since the $\mathrm{pH}$ dependent conformations of immobilized BSA were found to be indistinguishable from that of free BSA, immobilized BSA kept native like conformation and packed and concentrated immobilization on the particle surface made BSA conformation stiff and keeping away from quencher access. Fluorescence emission spectra of immobilized BSA on anionic PP in $10 \mathrm{mM}$ acetate buffer at $\mathrm{pH} 3.8$ revealed that the strong conjugation of BSA with anionic PP at a low immobilization amount and the state of BSA immobilized on anionic PP was similar to that of free BSA for maximum surface coverage. Therefore, immobilized BSA kept native like conformation. The role of global protein charge density matching in adsorption and immobilization is very important and we can reasonably explain the adsorption and the immobilization mechanism of BSA against anionic PP, cationic PP, and zwitterionic PP.

\section{Acknowledgment}

W.R.G and S.V. acknowledge financial support from the Research Council of Norway within the FRINAT program, project no. 177556/V30.

\section{References}

1. Arrondo JL, Goñi FM (1999) Structure and dynamics of membrane proteins as 
Citation: Yasuda M, Ono K, Nomura T, Brewer SH, Halskau Jr O, et al. (2015) BSA Adsorption and Immobilization onto Charged Monodisperse Polymer Nanoparticles. J Biosens Bioelectron 6: 183. doi:10.4172/2155-6210.1000183

studied by infrared spectroscopy. Prog Biophys Mol Biol 72: 367-405.

2. Baron MH, Revault M, Servagent-Noinville S, Abadie J, Quiquampoix H (1999) Chymotrypsin adsorption on montmorillonite: Enzymatic activity and kinetic FTIR structural analysis. J Colloid Interf Sci 214: 319-332.

3. Lapcík L, Lapcík L, De Smedt S, Demeester J, Chabrecek P (1998) Hyaluronan Preparation, Structure, Properties, and Applications. Chem Rev 98: 2663-2684.

4. Shang L, Wang Y, Jiang J, Dong S (2007) pH-dependent protein conformational changes in albumin:gold nanoparticle bioconjugates: a spectroscopic study. Langmuir 23: 2714-2721.

5. Xu X, Rothwarf DM, Scheraga HA (1996) Nonrandom distribution of the onedisulfide intermediates in the regeneration of ribonuclease $A$. Biochemistry 35 : 6406-6417.

6. Goldberg ME, Rudolph R, Jaenicke R (1991) A kinetic study of the competition between renaturation and aggregation during the refolding of denaturedreduced egg white lysozyme. Biochemistry 30: 2790-2797.

7. Ptitsyn OB (1995) Molten globule and protein folding. Adv Protein Chem 47 83-229.

8. Alexandrescu AT, Evans PA, Pitkeathly M, Baum J, Dobson CM (1993) Structure and dynamics of the acid-denatured molten globule state of alphalactalbumin: a two-dimensional NMR study. Biochemistry 32: 1707-1718.

9. Ogino $H$, Ishikawa $H(2001)$ Enzymes which are stable in the presence of organic solvents. J Biosci Bioeng 91: 109-116.

10. Ogino H, Uchiho T, Doukyu N, Yasuda M, Ishimi K, et al. (2007) Effect of exchange of amino acid residues of the surface region of the PST-01 protease on its organic solvent-stability. Biochem Biophys Res Commun 358: 10281033.

11. Klibanov AM (1983) Immobilized enzymes and cells as practical catalysts. Science 219: 722-727.

12. Mager PP, Penke B, Walter R, Harkany T, Hartignny W (2002) Pathological peptide folding in Alzheimer's disease and other conformational disorders. Current Medicinal Chemistry 9: 1763-1780.

13. Imai T, Sumi $Y$, Hatakeyama M, Fujimoto K, Kawaguchi $H$, et al. (1996) Selective Isolation of DNA or RNA Using Single-Stranded DNA Affinity Latex Particles. J Colloid Interface Sci 177: 245-249.

14. Frederic TW (1970) Determination of Organic Compounds: Methods and Procedures, Wiley-Interscience, New York.
15. Mateo C, Torres R, Fernandez-Lorente G, Ortiz C, Fuentes M, et al. (2003) Epoxy-amino groups: A new tool for improved immobilization of proteins by the epoxy method. Biomacromolecules 4: 772-777.

16. Bradford MM (1976) A rapid and sensitive method for the quantitation of microgram quantities of protein utilizing the principle of protein-dye binding. Anal Biochem 72: 248-254

17. Brunauer S, Emmett $\mathrm{PH}$, Teller $\mathrm{E}$ (1938) Adsorption of gases in multimolecular layers. J Am Chem Soc 60: 309-319.

18. Barrett EP, Joyner LG, Halenda PH (1951) The determination of pore volume and area distributions in porous substances. I Computations from nitrogen isotherms. J Am Chem Soc 73: 373-380.

19. Dockal M, Carter DC, Rüker F (2000) Conformational transitions of the three recombinant domains of human serum albumin depending on $\mathrm{pH}$. J Biol Chem 275: 3042-3050.

20. Anfinsen CB, Edsall JT, Richards FM, Eisenberg DS (1994) Advance in Protein Chemistry, Lipoproteins, Apolipoproteins and Lipases. DC Carter, JX Ho Chapter Structure of Serum Albumin. Academic Press Inc., San Diego.

21. Yihua Y, Yan S (1999) Macroporous poly(glycidyl methacrylate-trially isocyanurate- divinylbenzene) matrix as an anion-exchange resin for protein adsorption. J Chromatogra A 855: 129-136.

22. Carter DC, Ho JX (1994) Structure of serum albumin. Adv Protein Chem 45 153-203.

23. Bird RB, Stewart WE, Lightfoot EN (2002) Transport Phenomena. Wiley: New York.

24. Tsou HS, Graham EE (1985) Prediction of adsorption and desorption of protein on dextran based ion-exchange resin. AIChE J 31: 1959-1966.

25. Rezwan K, Meier LP, Rezwan M, Voros J, Textor M, et al. (2004) Bovine serum albumin adsorption onto colloidal $\mathrm{Al} 2 \mathrm{O} 3$ particles:? a new model based on zeta potential and uv-vis measurements. Langmuir 20: 10055-10061.

26. Glomm WR, Halskau O Jr, Hanneseth AM, Volden S (2007) Adsorption behavior of acidic and basic proteins onto citrate-coated Au surfaces correlated to their native fold, stability, and pl. J Phys Chem B 111: 14329-14345.

27. Tanford C, Swanson SA, Shore WS (1955) Hydrogen ion equilibria of bovine serum albumin. J Am Chem Soc 77: 6414-6421.

28. Stryer L (1978) Fluorescence energy transfer as a spectroscopic ruler. Annu Rev Biochem 47: 819-846. 